\section{Fla. 7775 and Fla. 7781: Tomato Breeding Lines Resistant to Fusarium Crown and Root Rot}

\author{
J.W. Scott ${ }^{1}$ and John Paul Jones \\ Gulf Coast Research and Education Center, 5007 60th Street East, University \\ of Florida, Institute of Food and Agricultural Sciences, Bradenton, FL 34203
}

Additional index words. disease resistance, fruit color, Fusarium oxysporum f. sp. radicuslycopersici, jointless pedicel, lycopene, Lycopersicon esculentum

Fla. 7775 and Fla. 7781 are jointless- and jointed-pedicel, fresh-market tomato (Lycopersicon esculentum Mill.) breeding lines, respectively, with resistance to Fusarium crown and root rot (FCR) incited by Fusarium oxysporum Schlechtend f. sp. radicuslycopersici W.R. Jarvis and Shoemaker. Resistance is conferred by the dominant gene $\mathrm{Frl}$ (Vakalounakis, 1988). No acceptable cultivars with FCR resistance are adapted to Florida conditions. These breeding line releases should be useful as parents in developing resistant hybrids and as sources of resistance to develop other resistant inbreds.

\section{Origin}

Seed of Fla. 7781 was increased in the $\mathrm{F}_{13}$ generation after a cross between Fla. 7440 and Fla. 7464 (Fig. 1). Several generations of single plant selection were required to obtain homozygosity for FCR resistance and jointed pedicels. Fla. 7464 is a globe-shaped, jointed, crimson $\left(o g^{c}\right)$ inbred resistant to FCR and Fusarium wilt incited by $F$. $o$. f. sp. lycopersici races 1,2 , and 3 . The FCR resistance traces back to Ohio 89-1, the resistant parent of 'Ohio CR-6' (Scott and Farley, 1983). The pedigree of 'Suncoast' (Scott et al., 1985b), Fla. 7228, and Fla. 7181 (Scott and Jones, 1995) were reported earlier. Fla. 7440 is a jointless-pedicel, crimson breeding line with a nippled blossom end ( $n-4)$ derived from NC 8276 (Gardner, 1992). The line EO1 is related to EO3, which has been described along with Fla. 7182 (Scott, 2000). The pedigrees of 'Hayslip' and 'Horizon' have been described (Augustine et al., 1981; Scott et al., 1985a).

One of the parents of Fla. 7775 was an $\mathrm{F}_{6}$ that diverged from Fla. 7781 in the $\mathrm{F}_{5}$ generation (Fig. 1). It was crossed with Fla. 7647B, a

Received for publication 19 July 1999. Accepted for publication 20 Jan. 2000. Florida Agricultural Experiment Station Journal Series No. R-06997. We thank Karen Pearce, Jan Watson, and Russell Owens for their excellent technical support. The cost of publishing this paper was defrayed in part by the payment of page charges. Under postal regulations, this paper therefore must be hereby marked advertisement solely to indicate this fact.

${ }^{1}$ To whom reprint requests should be addressed. E-mail: jwsc@gnv.ifas.ufl.edu

HortScience, Vol. 35(6), OCtober 2000 jointless, crimson breeding line whose parents, Fla. 7182 and Fla. 7340, were previously described (Scott, 2000).

\section{Description}

Fla. 7781. Fla. 7781 has a medium-tall, determinate $(s p)$ vine with good fruit cover. Pedicels are jointed and shoulder color is light
Fig. 1. Pedigree of Fla. 7775 and Fla. 7781. green $(u g)$. Fruit have good firmness. In Spring 1998, Fla. 7781 was firmer than 'Agriset 761' and comparable with 'Sanibel' (Table 1). Blossom scars are irregular and generally smooth but the scars can become rough under cool conditions. To obtain hybrids with adequate smoothness, we suggest that crosses be made with nipple blossom scar types. Fla. 7781 has midseason maturity. This was reflected in Spring 1998, where the early yield was significantly less than that of 'Equinox', comparable with that of 'Agriset 761', and significantly higher than that of 'Sanibel' (Table 1). Total yield was significantly less than for 'Equinox' but comparable with that of 'Agriset 761' and 'Sanibel'. Several hybrids with Fla. 7781 as a parent have performed well and produced large fruit in Florida yield trials (data not shown). Hybrids with adequate fruit size should be possible with many of the parents available to tomato breeders. External fruit color is acceptable. In Spring 1998, the external L score was significantly less than those of the other cultigens, indicating a darker value (Table 1). The a score, indicative of red pigment, was less than that of Fla. 7775 but the same as that of the

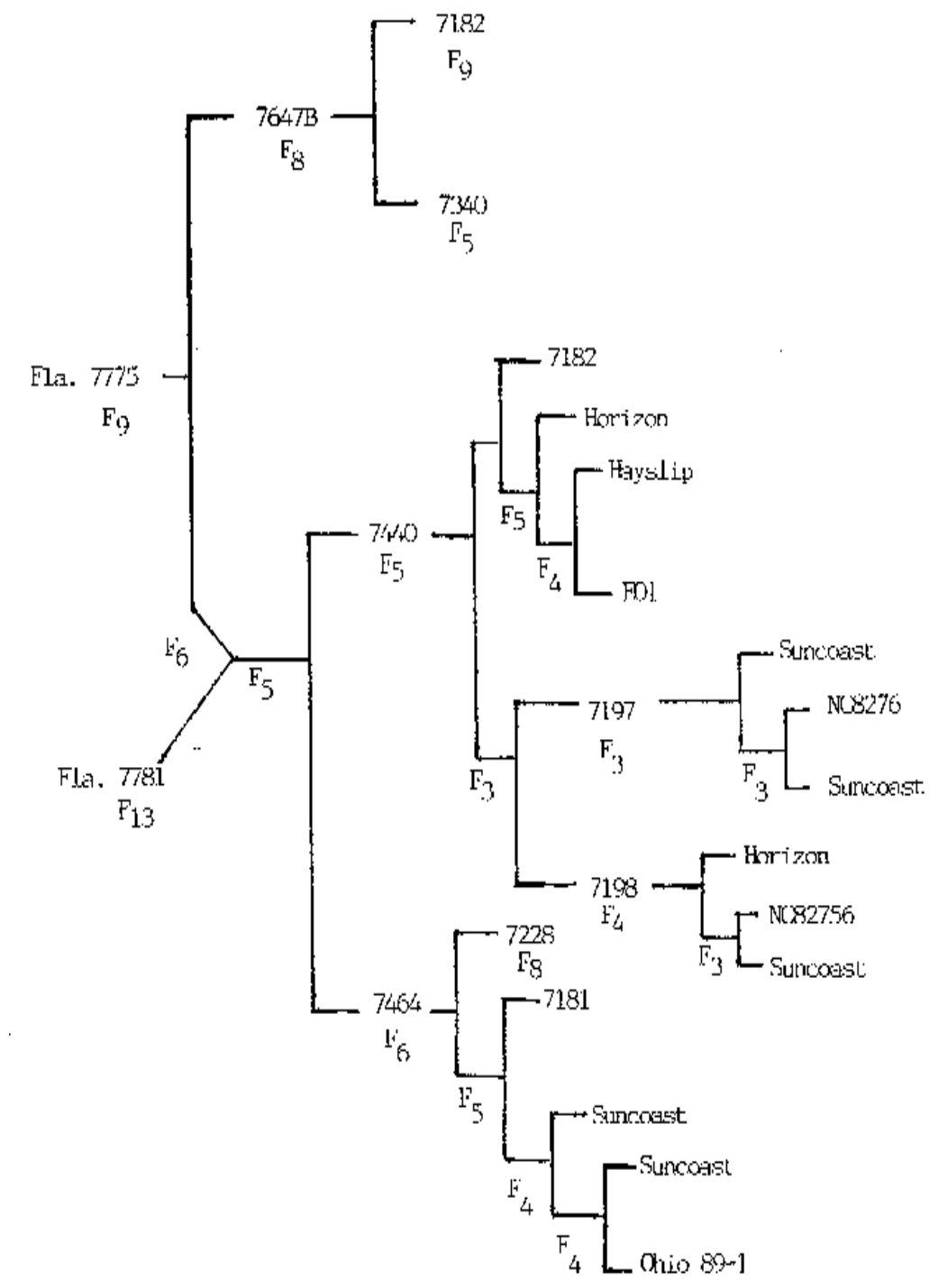


Table 1. Marketable yield, fruit firmness, and fruit color of tomato cultigens grown at Bradenton, Fla., in Spring 1998.

\begin{tabular}{|c|c|c|c|c|c|c|c|c|c|c|c|}
\hline \multirow[b]{3}{*}{ Cultigen } & \multirow{2}{*}{\multicolumn{2}{|c|}{$\begin{array}{c}\text { Marketable yield }{ }^{2} \\
\text { (kg/plant) }\end{array}$}} & \multirow{3}{*}{$\begin{array}{c}\text { Fruit } \\
\text { size } \\
\text { (g/fruit) }\end{array}$} & \multirow{3}{*}{$\begin{array}{l}\text { Culls } \\
(\%)\end{array}$} & \multirow{3}{*}{$\begin{array}{c}\text { Firmness }^{\mathrm{y}} \\
(\mathrm{mm} \\
\text { deformation })\end{array}$} & \multicolumn{6}{|c|}{ Fruit color $^{x}$} \\
\hline & & & & & & \multicolumn{3}{|c|}{ External } & \multicolumn{3}{|c|}{ Internal } \\
\hline & Early & Total & & & & L & $\mathrm{a}$ & $\mathrm{b}$ & $\mathrm{L}$ & a & b \\
\hline Fla. 7771 & $2.48 \mathrm{~b}^{\mathrm{w}}$ & $7.90 \mathrm{a}$ & $164 \mathrm{ab}$ & $14.5 \mathrm{c}$ & $5.3 \mathrm{bc}$ & $47.1 \mathrm{a}$ & $19.5 \mathrm{~b}$ & $42.3 \mathrm{a}$ & $51.6 \mathrm{ab}$ & $18.3 \mathrm{c}$ & $31.1 \mathrm{a}$ \\
\hline Fla. 7775 & $1.65 \mathrm{~cd}$ & $6.84 \mathrm{bc}$ & $155 \mathrm{~b}$ & $15.4 \mathrm{bc}$ & $3.5 \mathrm{~d}$ & $44.7 \mathrm{bc}$ & $24.8 \mathrm{a}$ & $38.1 \mathrm{bc}$ & $48.2 \mathrm{~cd}$ & $22.2 \mathrm{a}$ & $28.3 \mathrm{~b}$ \\
\hline Agriset 761 & $1.40 \mathrm{~d}$ & $6.31 \mathrm{~cd}$ & $159 a b$ & $25.9 \mathrm{ab}$ & $5.7 \mathrm{ab}$ & $45.3 \mathrm{ab}$ & $19.2 \mathrm{~b}$ & $38.8 \mathrm{~b}$ & $53.8 \mathrm{a}$ & $14.8 \mathrm{~d}$ & $28.6 \mathrm{~b}$ \\
\hline Sanibel & $0.59 \mathrm{e}$ & $6.19 \mathrm{~cd}$ & $179 \mathrm{a}$ & $23.5 \mathrm{a}-\mathrm{c}$ & $4.9 \mathrm{c}$ & $45.8 \mathrm{ab}$ & $20.8 \mathrm{~b}$ & $39.8 \mathrm{ab}$ & $48.9 \mathrm{~b}-\mathrm{d}$ & $19.5 \mathrm{bc}$ & $30.7 \mathrm{a}$ \\
\hline Fla. 7781 & $1.85 \mathrm{~b}-\mathrm{d}$ & $5.93 \mathrm{~cd}$ & $160 \mathrm{ab}$ & $28.3 \mathrm{a}$ & $4.6 \mathrm{c}$ & $43.4 \mathrm{c}$ & $20.6 \mathrm{~b}$ & $35.7 \mathrm{c}$ & $46.0 \mathrm{~d}$ & $22.0 \mathrm{ab}$ & $24.1 \mathrm{c}$ \\
\hline
\end{tabular}

${ }^{\mathrm{i}}$ Fruit at breaker stage or beyond were harvested three times at weekly intervals; early harvest was from the first harvest. A completely randomized block design was used, with three blocks and 10 plants per plot.

${ }^{\mathrm{y}}$ Measured for $5 \mathrm{~s}$ with a pressure tester with a 1-kg weight and a $1.5-\mathrm{cm}$ contact plate. The contact plate was placed over locules on 10 fruit per cultigen per block (3). Lower values indicate firmer fruit.

${ }^{x}$ Determined with a Minolta CR-300 Chroma Meter (Minolta Camera Co., Osaka, Japan). External color taken in equatorial plane of fruit; internal color of each fruit was an average of readings from three locations: pericarp, placenta, and locule. There were 10 fruit per cultigen per block.

w'Mean separation within columns by Duncan's multiple range test at $P \leq 0.05$.

other cultigens tested. The $b$ score, indicative of yellow pigment, was similar to that of Fla. 7324 and Fla. 7775, but less than that of the other cultigens. Internal color is deep red, in part due to the action of the $o g^{\mathrm{c}}$ gene, which intensifies red pigment. This was reflected in the relatively high a score in Spring 1998 (Table 1). Fla. 7781 had a lower b score than did the other cultigens, indicating less yellow, and a lower internal L score than did some cultigens, indicating a darker value compared with some cultigens. On a scale of 1 to 5 where $1=$ poor, $3=$ acceptable, and $5=$ excellent, the flavor of Fla. 7781 over several seasons was rated a 3 by the senior author and a technician.

Fla. 7775 . Fla. 7775 has a medium-sized $(s p)$ vine with fair fruit cover. Foliage tends to be less dense than that of Fla. 7781 and many other cultivars grown in Florida. For commercial hybrids, crossing with lines possessing vigorous vines would be advisable. Pedicels are jointless $(j-2)$, fruit shoulders are light green $(u g)$, and fruit are very firm. In Spring 1998, fruit of Fla. 7775 were significantly firmer than that of all the other cultigens evaluated (Table 1). Blossom scars are stellate and have been smooth under a wide range of conditions. This was reflected in the relatively low cull percentage in the Spring 1998 trial. Fla. 7775 is of midseason maturity and was comparable in early yield with 'Agriset 761' and earlier than 'Sanibel' in the Spring 1998 trial (Table 1). Yield has been good in the spring, but not in the fall (data not shown) in Bradenton, which is typical of most jointless cultigens. In Spring 1998, Fla. 7775 had total yields comparable with all cultigens tested except Fla. 7771, which yielded more, and Fla. 7324, which yielded less. Fla. 7324 is the heat-tolerant parent of 'Equinox'. Fruit size (weight) has been medium-large; in Spring 1998, Fla. 7775 fruits were smaller than 'Sanibel', larger than Fla. 7324, and similar to fruits of other cultigens evaluated (Table 1). Fruit ripen well and have good external color. In Spring 1998, Fla. 7775 had the highest score for red (a) color of all cultigens tested. Internal color is very good, largely because the $\sigma^{\mathrm{c}}$ gene conferring a deeper

Table 2. Response of tomato genotypes to inoculation with Fusarium oxysporum $\mathrm{f}$. sp. radicus-lycopersici $\left(10^{7}\right.$ spores $\left./ \mathrm{mL}\right)$ at the cotyledon stage $\left(2{ }^{\circ} \mathrm{C}\right.$ day $/ 18^{\circ} \mathrm{C}$ night $)$ and tomato mosaic virus strain 2 .

\begin{tabular}{|c|c|c|c|c|c|c|}
\hline \multirow[b]{2}{*}{ Genotype $^{z}$} & \multicolumn{3}{|c|}{ Fusarium crown rot inoculation } & \multicolumn{3}{|c|}{ Tomato mosaic virus inoculation } \\
\hline & $\begin{array}{c}\text { Total } \\
\text { plants (no.) }\end{array}$ & $\begin{array}{c}\text { Healthy } \\
\text { plants }(\%)\end{array}$ & $\begin{array}{c}\text { Diseased } \\
\text { plants }(\%)\end{array}$ & $\begin{array}{c}\text { Total } \\
\text { plants (no.) }\end{array}$ & $\begin{array}{c}\text { Healthy } \\
\text { plants }(\%)\end{array}$ & $\begin{array}{c}\text { Diseased } \\
\text { plants }(\%)\end{array}$ \\
\hline Fla. 7781 & 94 & 96 & 4 & 73 & 14 & 86 \\
\hline Fla. 7775 & 119 & 100 & 0 & 118 & 99 & 1 \\
\hline Ohio 89-1 & 164 & 98 & 2 & 18 & 100 & 0 \\
\hline Fla. 7547 & 157 & 13 & 87 & 32 & 3 & 97 \\
\hline Fla. 7060 & --- & --- & --- & 18 & 0 & 100 \\
\hline
\end{tabular}

${ }^{2}$ Ohio 89-1 (Frl, Tm2) was the resistant control for both diseases, Fla. $7547\left(F r 1^{+}, T m 2^{+}\right)$was a susceptible control for both diseases, and Fla. $7060\left(T m 2^{+}\right)$was a susceptible control for tomato mosaic virus.

red a score (Table 1). The yellow component (b) was intermediate among the cultigens tested in Spring 1998. Flavor on the scale mentioned previously would be a 3 but is quite mild.

Disease resistance. Fla. 7775 and Fla. 7781 contain the $\mathrm{Frl}$ gene (Vakalounakis, 1988), conferring resistance to FCR (Table 2). They are also resistant to races 1 and 2 of Fusarium wilt caused by Fusarium oxysporum Schlechtend f. sp. lycopersici (Sacc.) Snyder \& Hansen $(I, I-2)$, Verticillium wilt race 1 caused by Verticillium dahliae Kleb. (Ve), and gray leafspot caused by Stemphyllium solani Weber (Sm). Fla. 7775 also has the Tm2 gene conferring resistance to tomato mosaic virus races 0,1 , and 2 , which was derived from Ohio 89-1 (Scott and Farley, 1983), but Fla. 7781 lost the Tm2 gene and is susceptible (Table 2). The sequence characterized amplified region (SCAR) OPB 12 that is closely linked to the Tm-2 locus (Motoyoshi et al., 1996) was present in Fla. 7775 but not in Fla. 7781, confirming the results in Table 2. They are both tolerant of all fruit disorders although some minor zippering, spider track, and cuticle cracking have occurred in Fla. 7775, and some radial bursting and cuticle cracking have occurred in Fla. 7781 . Both have had a minor amount of blossom-end rot.

\section{Availability}

Fla. 7775 and Fla. 7781 are inbred breeding line releases. Seed is distributed through the Florida Foundation Seed Producers, P.O.
Box 309, Greenwood, FL 32443. Small samples for research purposes are available from the senior author.

\section{Literature Cited}

Augustine, J.J., R.B. Volin, H.H. Bryan, P.H. Everett, D.S. Burgis, and D.D. Gull. 1981. Hayslip, a jointless fresh-market tomato. Florida Agr. Expt. Sta. Circ. S-278.

Gardner, R.W. 1992. 'Mountain Spring' tomato; NC 8276 and NC 84173 tomato. HortScience 27:1233-1234.

Motoyoshi, Fusao, Taku Ohmori, and Minoru Murata. 1996. Molecular characterization of heterochromatic regions around the $T m$ - 2 locus in chromosome 9 of tomato. Symp. Soc. Expt. Biol. 50:65-70.

Scott, J.W. 2000. Fla. 7771, a medium-large, heattolerant, jointless-pedicel tomato. HortScience 35:968-969.

Scott, J.W., J.A. Bartz, H.H. Bryan, P.H. Everett, D.D. Gull, T.K. Howe, P.J. Stoffella, and R.B. Volin. 1985a. Horizon, a fresh market tomato with concentrated fruit set. Florida Agr. Expt. Sta. Circ. S-323.

Scott, J.W., P.H. Everett, H.H. Bryan, D.D. Gull, T.K. Howe, P.J. Stoffella, and R.B. Volin. 1985b. Suncoast, a large-fruited home garden tomato. Florida Agr. Expt. Sta. Circ. S-322.

Scott, J.W. and J.D. Farley. 1983. 'Ohio CR-6' tomato. HortScience 18:114-115.

Scott, J.W. and J.P. Jones. 1995. Fla. 7547 and Fla. 7481 tomato breeding lines resistant to Fusarium oxysporum f.sp. lycopersici races 1, 2, and 3 . HortScience 30:645-646.

Vakalounakis, D.J. 1988. The genetic analysis of resistance to fusarium crown and root rot of tomato. Plant Pathol. 37:71-73. 